\title{
Characterization of halobenzoate-degrading, denitrifying Azoarcus and Thauera isolates and description of Thauera chlorobenzoica sp. nov.
}

\author{
Bongkeun Song, ${ }^{1}+$ Norberto J. Palleroni, ${ }^{1}$ Lee J. Kerkhof ${ }^{2}$ \\ and Max M. Häggblom ${ }^{1}$
}

Department of

Biochemistry and

Microbiology and

Biotechnology Center for

Agriculture and the

Environment ${ }^{1}$ and Institute

for Marine and Coastal

Sciences ${ }^{2}$, Cook College,

Rutgers - The State

University of New Jersey,

New Brunswick,

NJ 08901-8525, USA
Author for correspondence: Max M. Häggblom. Tel: +1 7329329763 ext. 326. Fax: +1 7329328965. e-mail: haggblom@aesop.rutgers.edu

The taxonomic relationships of Azoarcus and Thauera isolates in the $\beta$-subclass of the Proteobacteria capable of degrading fluoro-, chloro- or bromobenzoate under denitrifying conditions were analysed. A detailed classification of these strains was performed using a polyphasic approach, which included studies on morphology, phenotypic characterization, fatty acid analysis, 16S rRNA gene sequence analysis, 16S rRNA gene mapping (ribotyping) and DNA-DNA hybridization. The analyses of fatty acids and 165 rRNA gene sequencing differentiated strains 2FB2, 2 FB6 and 4FB10 as new members of the genus Azoarcus and strains 4FB1, 4FB2, 3CB2, 3CB3 and 3BB1 as new members of the genus Thauera. DNA-DNA hybridization experiments established that strains 2FB2, 2FB6 and 4FB10 belong to the species Azoarcus tolulyticus. Strains 3CB2 and 3 СB3 were assigned to the species Thauera aromatica on the basis of DNA-DNA hybridization and ribotyping experiments. Strains 4FB1, 4FB2 and 3BB1 showed close relatedness with strain $3 \mathrm{BB}^{\top}{ }^{\top}$, previously described as $T$. aromatica genomovar chlorobenzoica. This group of strains is clearly differentiated from the species $T$. aromatica on the basis of 16S rRNA sequence analysis, DNA homology and ribotyping analysis. Strains 3CB-1', 4FB1, 4FB2 and 3BB1 are proposed as members of the new species Thauera chlorobenzoica sp. nov., strain ${ }^{3 C B-1}{ }^{\top}$ ( = ATCC $700723^{\top}$ ) being the type strain.

Keywords: Azoarcus, Thauera, halobenzoate degradation

\section{INTRODUCTION}

Several bacterial strains capable of growing at the expense of aromatic compounds under denitrifying conditions have been assigned to the genera Azoarcus and Thauera (Anders et al., 1995; Gallus et al., 1997; Harms et al., 1999; Häggblom \& Young, 1999; Rabus \& Widdel, 1995; van Schie \& Young, 1998; Song et al., 1998, 1999, 2000a; Springer et al., 1998; Zhou et al., 1995). These closely related genera seem to constitute a major group of denitrifying bacteria capable of degrading aromatic compounds. Thus far, the genus

\footnotetext{
† Present address: Department of Geosciences, Princeton University, NJ 08544-1003, USA.

The GenBank/EMBL/DDBJ accession numbers for the 16S rRNA sequences described in this work are AF229857 (strain 2FB2), AF229862 (strain 2FB6), AF229874 (strain 4FB10), AF229867 (strain 4FB1), AF229868 (strain 4FB2), AF229881 (strain 3CB2), AF229882 (strain 3CB3) and AF229887 (strain 3BB1).
}

Azoarcus is represented by seven species. On the basis of cell morphology and the ability to fix nitrogen, it was proposed that strains isolated from the rhizosphere microflora of Kallar grass were Azoarcus indigens and Azoarcus communis (Reinhold-Hurek et al., 1993). Later, a new species capable of degrading aromatic compounds was described under the name Azoarcus evansii (Anders et al., 1995). Toluene-degrading denitrifiers were initially assigned to a new species, Azoarcus tolulyticus (Zhou et al., 1995), but more detailed taxonomic examination resulted in reclassification and the proposal of two additional species, Azoarcus toluvorans and Azoarcus toluclasticus (Song et al., 1999). Finally, the species Azoarcus anaerobius was assigned to the genus as an obligately denitrifying bacterium with the capacity to degrade $\alpha$ resorcinol (Springer et al., 1998).

The genus Thauera was proposed to accommodate the single species Thauera selenatis, represented by one 
strain, which is capable of selenate reduction (Macy et $a l .$, 1993). Additional strains of the genus have been assigned to the species Thauera aromatica, which has the capacity to degrade aromatic compounds, including toluene, phenol, $m$-xylene and chlorobenzoate, under denitrifying conditions (Anders et al., 1995; Foss \& Harder, 1998; Gallus et al., 1997; Häggblom \& Young, 1999; Rabus \& Widdel, 1995; Song et al., 1998, 2000a). Terpene-degrading denitrifiers were assigned to two new species of the genus, Thauera linaloolentis and Thauera terpenica (Foss \& Harder, 1998). Recently, the species Thauera mechernichensis was reported as having an aerobic denitrification property (Scholten et al., 1999). Unfortunately, most of the species are represented by single strains, which conspires against an evaluation of the important question of intraspecies diversity.

In previously described work from our laboratory, strains capable of mineralizing halobenzoates under denitrifying conditions were isolated from samples collected at various geographical and ecological sites (Song et al., 2000b). These strains were assigned to nine genera belonging to either the $\alpha-, \beta$ - or $\gamma$ Proteobacteria. Eight strains isolated from estuarine sediments from the Arthur Kill intertidal strait in New York state, Sihwa Lake in Korea and agricultural soil from Wyoming were tentatively assigned to the genera Azoarcus and Thauera (Song et al., 2000b). In this communication, we provide more detailed classification of the isolates on the basis of morphological and physiological characterization, cellular fatty acid profiles, phylogenetic analysis of the 16S rRNA gene, 16S rRNA gene mapping and the results of DNADNA hybridization experiments. On the basis of these results, we propose the new species Thauera chlorobenzoica $\mathrm{sp}$. nov. and designate $3 \mathrm{CB}-1^{\mathrm{T}}(=\mathrm{ATCC}$ $700723^{\mathrm{T}}$ ) as the type strain.

\section{METHODS}

Organisms and growth conditions. All of the strains, including halobenzoate-degrading, denitrifying isolates and reference strains of the genera Azoarcus and Thauera, together with their geographical and ecological origins, are listed in Table 1. All of the strains of Thauera (with the exception of $T$. selenatis $\mathrm{AX}-1^{\mathrm{T}}$ and $T$. mechernichensis $\mathrm{TL}^{\mathrm{T}}$ ) and Pseudomonas stutzeri ATCC $17588^{\mathrm{T}}$ were cultivated anaerobically in a minimal salts medium (Tschech \& Fuchs, 1987) with succinate as the carbon source and nitrate as the electron acceptor. $T$. selenatis was grown in a vitaminamended medium as described previously (Song et al. 2000a) and T. mechernichensis was cultured aerobically in LuriaBertani broth. All of the strains of Azoarcus were grown on M-R2A medium as described previously (Song et al., 1999).

Morphology and physiological tests. Cell dimensions and morphology were determined by using phase-contrast microscopy. Flagellation was assessed according to Leifson (1951). The presence of catalase and oxidase was tested as described previously (Smibert \& Krieg, 1994). The utilization of aromatic compounds (Aldrich; minimum $97 \%$ purity) was tested with dense cell suspensions $\left(\mathrm{OD}_{620}=0 \cdot 8\right)$ and substrates at $200 \mu \mathrm{M}$ under aerobic and denitrifying conditions. Growth on toluene was determined in an anaerobic toluene atmosphere as described previously (Evans et al., 1991). Growth on various other substrates was determined at $30^{\circ} \mathrm{C}$ under both aerobic and denitrifying conditions, using minimal salts medium plates (Tschech \& Fuchs, 1987) containing $1 \mathrm{mM}$ final concentrations of acetate, adipate, D-alanine, L-asparagine, betaine, butyrate, caproate, ethanol, fructose, glucose, glutamate, lactose, malate, ornithine, pyruvate, succinate or valerate.

Determination of cellular fatty acids. All of the strains were pre-cultured under denitrifying conditions in minimal salts medium (Tschech \& Fuchs, 1987) with $10 \mathrm{mM}$ succinate and $30 \mathrm{mM}$ nitrate. After the $\mathrm{OD}_{620}$ of the cultures had reached $0 \cdot 4$, the cells were used as an inoculum $(10 \%)$ to $50 \mathrm{ml}$ fresh liquid medium containing $10 \mathrm{mM}$ succinate and $30 \mathrm{mM}$ nitrate, in anaerobic serum bottles, and cultivated for $24 \mathrm{~h}$ at $30{ }^{\circ} \mathrm{C}$ under an argon atmosphere. The cells were collected by centrifugation at room temperature. Fatty acids were saponified, methylated, extracted and analysed by GC, using the SHERLOCK Microbial Identification System (MIDI).

Genomic bacterial DNA isolation. Chromosomal DNA from each strain was isolated as described previously (Song et al., 1998). The extracted DNA was sheared by two passages through a French press at 20000 p.s.i. (138000 kPa) and diluted to $0.4 \mathrm{mg}$ DNA ml ${ }^{-1}$. The purity of the DNA was determined by measuring the absorbance at 230, 260 and $280 \mathrm{~nm}$. In all cases, the $A_{260} / A_{280}$ and $A_{260} / A_{230}$ ratios were close to 2 .

Measurement of $\mathbf{G}+\mathbf{C}$ content. The $\mathrm{G}+\mathrm{C}$ content of DNA was measured by HPLC (Mesbah et al., 1989), with some modifications. Phosphate/methanol buffer (90:10) was used at a flow rate of $1.5 \mathrm{ml} \mathrm{min-}{ }^{1}$ as a solvent for the separation of deoxyribonucleosides and ribonucleosides. Phosphate buffer ( $\mathrm{pH} 4 \cdot 0$ ) was prepared by dissolving $\mathrm{KH}_{2} \mathrm{PO}_{4}$ $(0.049 \mathrm{M})$ in distilled water and adjusting the $\mathrm{pH}$ with $85 \%$ $\mathrm{H}_{3} \mathrm{PO}_{4}$. The nucleosides were analysed by using a model LC10AS HPLC (Shimadzu), with a reverse-phase C18 column (Spherisorb $4.6 \times 250 \mathrm{~mm}, 5 \mu \mathrm{m}$ particle size; Phenomenex), and the absorbance was monitored at a wavelength of $254 \mathrm{~nm}$.

Determination and analysis of 16S rRNA gene sequences. PCR amplifications of the 16S rRNA genes of strains were performed with a GeneAmp PCR system 2400, as described previously (Song et al., 1998). The complete sequence of the 16S rRNA gene was obtained by using internal 16S rRNA oligonucleotide sequencing primers $27 \mathrm{~F}, 321 \mathrm{R}, 357 \mathrm{~F}, 685 \mathrm{R}$, 704F, 907R, 1242F and 1522R (Johnson, 1994a) and a model ABI 377A automated sequencer (Perkin Elmer).

The rRNA gene sequences of reference strains and species in the genera Thauera and Azoarcus were obtained from the GenBank database. All of the sequences were aligned using the PILEUP program of the Genetics Computer Group software package (Devereux et al., 1984). Phylogenetic analysis was carried out according to Kimura's two-parameter method (Kimura, 1980) and a tree was reconstructed using the neighbour-joining method (Saitou \& Nei, 1987). The SEQBOOT program was used to obtain the confidence level for neighbour-joining analysis using a 100 bootstrapped dataset (Felsenstein, 1985).

The nucleotide sequence accession numbers of the reference strains used in this study are as follows (in parentheses): $T$. aromatica $\mathrm{K} 172^{\mathrm{T}}$ (X77118), T. aromatica T1 (U95176), $T$. 
Table 1. Geographical and ecological origins of strains used in this study

\begin{tabular}{|c|c|c|c|}
\hline Species & Strain & Geographical and ecological source & Reference(s) \\
\hline \multicolumn{4}{|l|}{ Azoarcus } \\
\hline A. indigens & $\operatorname{VB} 32^{\mathrm{T}}\left(=\right.$ LMG $\left.9092^{\mathrm{T}}\right)$ & Rhizosphere of Kallar grass, Brisbane, Australia & Reinhold-Hurek et al. (1993) \\
\hline A. tolulyticus & $\operatorname{Tol}^{\mathrm{T}}\left(=\right.$ ATCC $\left.51758^{\mathrm{T}}\right)$ & Aquifer sediment, Moffett Field, MI USA & Zhou et al. (1995) \\
\hline A. toluclasticus & $\operatorname{MF}^{\mathrm{T}}\left(=\operatorname{ATCC} 700605^{\mathrm{T}}\right)$ & Aquifer sediment, Moffett Field, MI, USA & Fries et al. (1994), Song et al. (1999) \\
\hline A. toluvorans & $\operatorname{Td} 21^{\mathrm{T}}\left(=\operatorname{ATCC} 700604^{\mathrm{T}}\right)$ & Muck soil, Clinton, MI, USA & Fries et al. (1994), Song et al. (1999) \\
\hline A. evansii & $\mathrm{KB} 740^{\mathrm{T}}\left(=\mathrm{DSM} 6898^{\mathrm{T}}\right)$ & Creek sediment, USA & Braun \& Gibson (1984), Anders et al. (1995) \\
\hline Azoarcus sp. & $2 \mathrm{FB} 2$ & Estuarine sediment, Arthur Kill, NJ, USA & Song et al. (2000b) \\
\hline Azoarcus sp. & 2FB6 & Estuarine sediment, Arthur Kill, NJ, USA & Song et al. (2000b) \\
\hline Azoarcus sp. & $4 \mathrm{FB} 10$ & Estuarine sediment, Sihwa, Korea & Song et al. (2000b) \\
\hline \multicolumn{4}{|l|}{ Thauera } \\
\hline T. selenatis & $\operatorname{AX}^{\mathrm{T}}\left(=\operatorname{ATCC} 55363^{\mathrm{T}}\right)$ & Selenium-contaminated water, CA, USA & Macy et al. (1993) \\
\hline T. aromatica & $\mathrm{K} 172^{\mathrm{T}}\left(=\mathrm{DSM} 6984^{\mathrm{T}}\right)$ & Anaerobic sludge, Konstanz, Germany & Tschech \& Fuchs (1987), Anders et al. (1995) \\
\hline T. aromatica & $\mathrm{T} 1$ (= ATCC 700265) & Petroleum-contaminated soil, CA, USA & Evans et al. (1991), Song et al. (1998) \\
\hline T. aromatica & AR-1 (= DSM 11528) & Activated sewage sludge, Germany & Gallus et al. (1997) \\
\hline T. aromatica gv. chlorobenzoica & $3 \mathrm{CB}-1^{\mathrm{T}}\left(=\operatorname{ATCC} 700723^{\mathrm{T}}\right)$ & River sediment, Albany, NY, USA & Häggblom \& Young (1999), Song et al. (2000a) \\
\hline T. linaloolentis & $47 \mathrm{Lol}^{\mathrm{T}}\left(=\mathrm{DSM} 12138^{\mathrm{T}}\right)$ & Activated sewage sludge, Germany & Foss \& Harder (1998) \\
\hline T. terpenica & $58 \mathrm{Eu}^{\mathrm{T}}\left(=\mathrm{DSM} 12139^{\mathrm{T}}\right)$ & Activated sewage sludge, Germany & Foss \& Harder (1998) \\
\hline T. terpenica & $21 \mathrm{Mol}$ ( = DSM 12140) & Activated sewage sludge, Germany & Foss \& Harder (1998) \\
\hline T. mechernichensis & $\operatorname{TL1}^{\mathrm{T}}\left(=\mathrm{DSM} 12266^{\mathrm{T}}\right)$ & Leachate, Mechernich, Germany & Scholten et al. (1999) \\
\hline Thauera sp. & $4 \mathrm{FB} 1$ & Estuarine sediment, Arthur Kill, NJ, USA & Song et al. (2000b) \\
\hline Thauera sp. & $4 \mathrm{FB} 2$ & Estuarine sediment, Arthur Kill, NJ, USA & Song et al. (2000b) \\
\hline Thauera sp. & $3 \mathrm{CB} 2$ & Estuarine sediment, Arthur Kill, NJ, USA & Song et al. (2000b) \\
\hline Thauera sp. & $3 \mathrm{CB} 3$ & Agricultural soil, WY, USA & Song et al. (2000b) \\
\hline Thauera sp. & 3BB1 & Agricultural soil, WY, USA & Song et al. (2000b) \\
\hline
\end{tabular}

gv., Genomovar.

aromatica mXyN1 (X83533), T. aromatica genomovar chlorobenzoica $3 \mathrm{CB}-1^{\mathrm{T}} \quad(\mathrm{AF} 123264), \quad T$. selenatis $\mathrm{AX}^{\mathrm{T}}$ (X68491), T. mechernichensis $\mathrm{TL1}^{\mathrm{T}}$ (Y17590), T. linaloolentis 47 $\mathrm{Lol}^{\mathrm{T}}$ (AJ005817), T. terpenica 58Eu ${ }^{\mathrm{T}}$ (AJ005817), $A$. evansii $\mathrm{KB}^{\mathrm{T}}{ }^{\mathrm{T}}$ (X77679), $A$. tolulyticus $\mathrm{Tol4}^{\mathrm{T}}$ (L33687), A. tolulyticus Td1 (L33687), A. tolulyticus Td2 (L33691), A. toluvorans $\mathrm{Td} 21^{\mathrm{T}}$ (L33692), A. toluclasticus $\mathrm{MF}^{2} 3^{\mathrm{T}}$ (AF123077), A. anaerobius LuFRes $1^{\mathrm{T}}$ (Y14701), A. indigens $\mathrm{VB}^{\mathrm{T}}$ (AF011345) and $A$. communis $\mathrm{Swub}^{\mathrm{T}}$ (AF011343).

DNA-DNA hybridization. The DNA preparations were labelled using the BRL nick translation kit with ${ }^{3} \mathrm{H}-$ radiolabelled dTTP. DNA-DNA hybridization was performed using the S1 nuclease method (Johnson, 1994b), with the modification of Song et al. (1998). The reannealing temperature was $68 \cdot 3^{\circ} \mathrm{C}$.

DNA homology value transformation. The construction of a three-dimensional model for the DNA homology values was performed with the program 3D; this calculated threedimensional co-ordinates by using the DNA homology value (Hildebrand et al., 1982). The accuracy, limitations and predictability of the program have been reported elsewhere (Hildebrand et al., 1984).

Restriction mapping of small-subunit rRNA (ribotyping). Strains belonging to the genus Thauera were tested for differences in genomic structures by mapping small-subunit rRNA genes. $T$. aromatica strains $\mathrm{K} 172^{\mathrm{T}}$ and $\mathrm{T} 1$ and strain $3 \mathrm{CB}-1^{\mathrm{T}}$ were used for comparison. The genomic DNAs of the strains were digested with restriction endonucleases $B g l \mathrm{I}$, $E c o$ RI and EcoRV. These enzymes were selected because sequence analysis indicated internal cut sites in the smallsubunit genes. The digested samples were run on a $1 \%$ agarose gel and transferred to nylon membranes (Boehringer Mannheim).

Samples were probed with a digoxigenin-labelled, $500 \mathrm{bp}$ fragment from the 5'-end of the Escherichia coli 16S rRNA gene, as described previously (Kerkhof \& Speck, 1997).
Genomic Southern blots were performed according to standard methods (Maniatis et al., 1982) with $65^{\circ} \mathrm{C}$ as the hybridization temperature and using the colorimetric substrates NBT and X-phosphate for visualization.

\section{RESULTS AND DISCUSSION}

\section{$16 S$ rRNA gene sequence analysis}

A comparative analysis of the almost complete sequences of the $16 \mathrm{~S}$ rRNA genes differentiated the halobenzoate-degrading strains into three groups located in the genera Azoarcus and Thauera (Fig. 1). Isolates 2FB2, 2FB6 and 4FB10 belong to the genus Azoarcus (Fig. 1) and are closely related to $A$. tolulyticus Tol $^{\mathrm{T}}$, having sequence similarities of $98 \cdot 2$, 99.2 and $98.6 \%$, respectively. Isolates 3CB2, 3CB3, $3 \mathrm{BB} 1,4 \mathrm{FB} 1$ and 4FB2 are located in the genus Thauera (Fig. 1). Isolates 3CB2 and 3CB3 are near to $T$. aromatica $\mathrm{K} 172^{\mathrm{T}}$, having sequence similarities of $99 \cdot 4$ and $99 \cdot 2 \%$, and isolates 4FB1, 4FB2 and 3BB1 are located close to $T$. aromatica genomovar chlorobenzoica $3 \mathrm{CB}-1^{\mathrm{T}}$ and $T$. mechernichensis, having sequence similarities of more than $98 \%$.

\section{Determination of cellular fatty acids}

Cluster analysis of cellular fatty acid profiles (Fig. 2) showed agreement with the phylogenetic analysis of $16 \mathrm{~S}$ rDNA for the grouping of the halobenzoatedegrading strains into the genera Azoarcus and Thauera. Strain 4FB10 was located near to $A$. tolulyticus, strains 2FB2 and 2FB6 were close to $A$. toluclasticus and the strains belonging to the genus Thauera were located in the cluster of $T$. aromatica. 


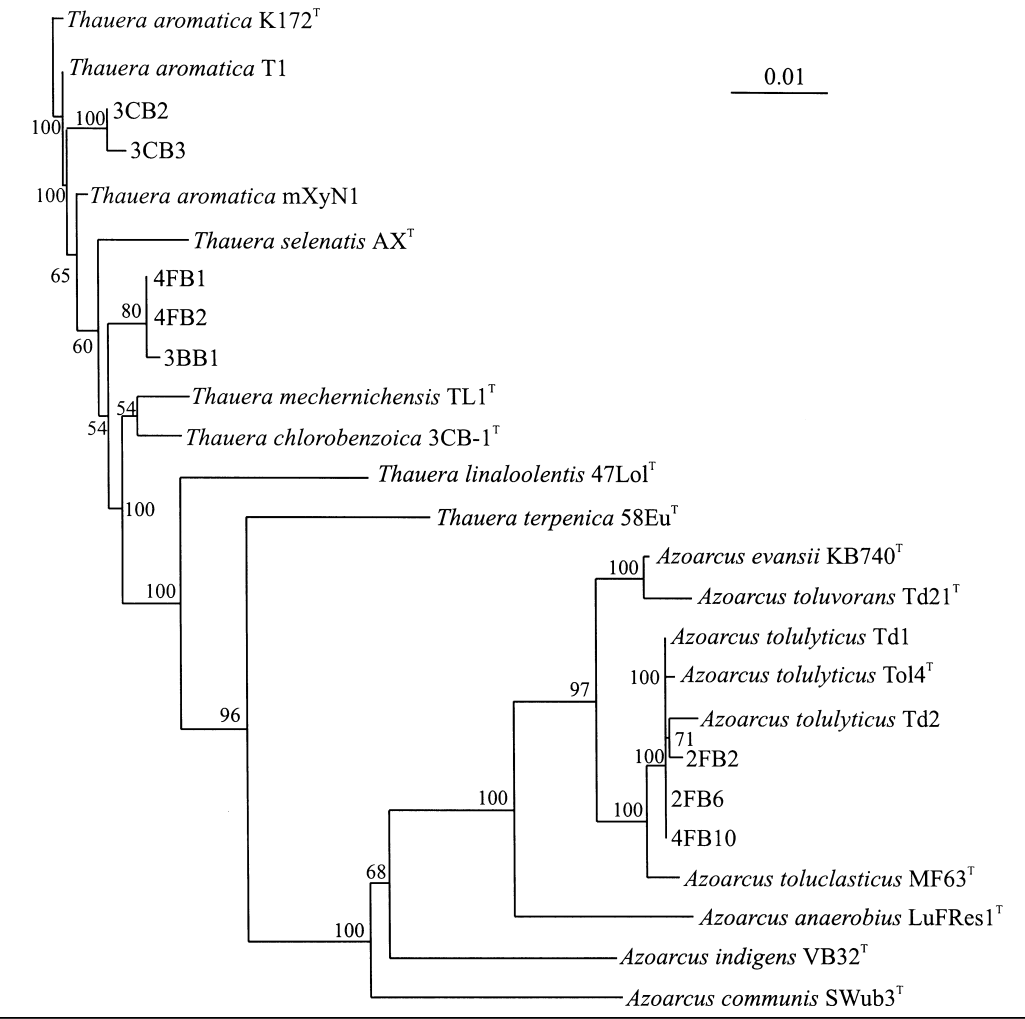

Fig. 1. Phylogenetic analysis of $16 \mathrm{~S}$ rRNA genes from halobenzoate-degrading isolates with the species of the genera Azoarcus and Thauera of the $\beta$-subclass of the Proteobacteria; 1500 bases were used to build the tree. Neighbour-joining topology was used for tree construction. Bootstrap percentages $(>50 \%)$ are shown at nodes. Bar, 1 nucleotide substitution in 100 bases.
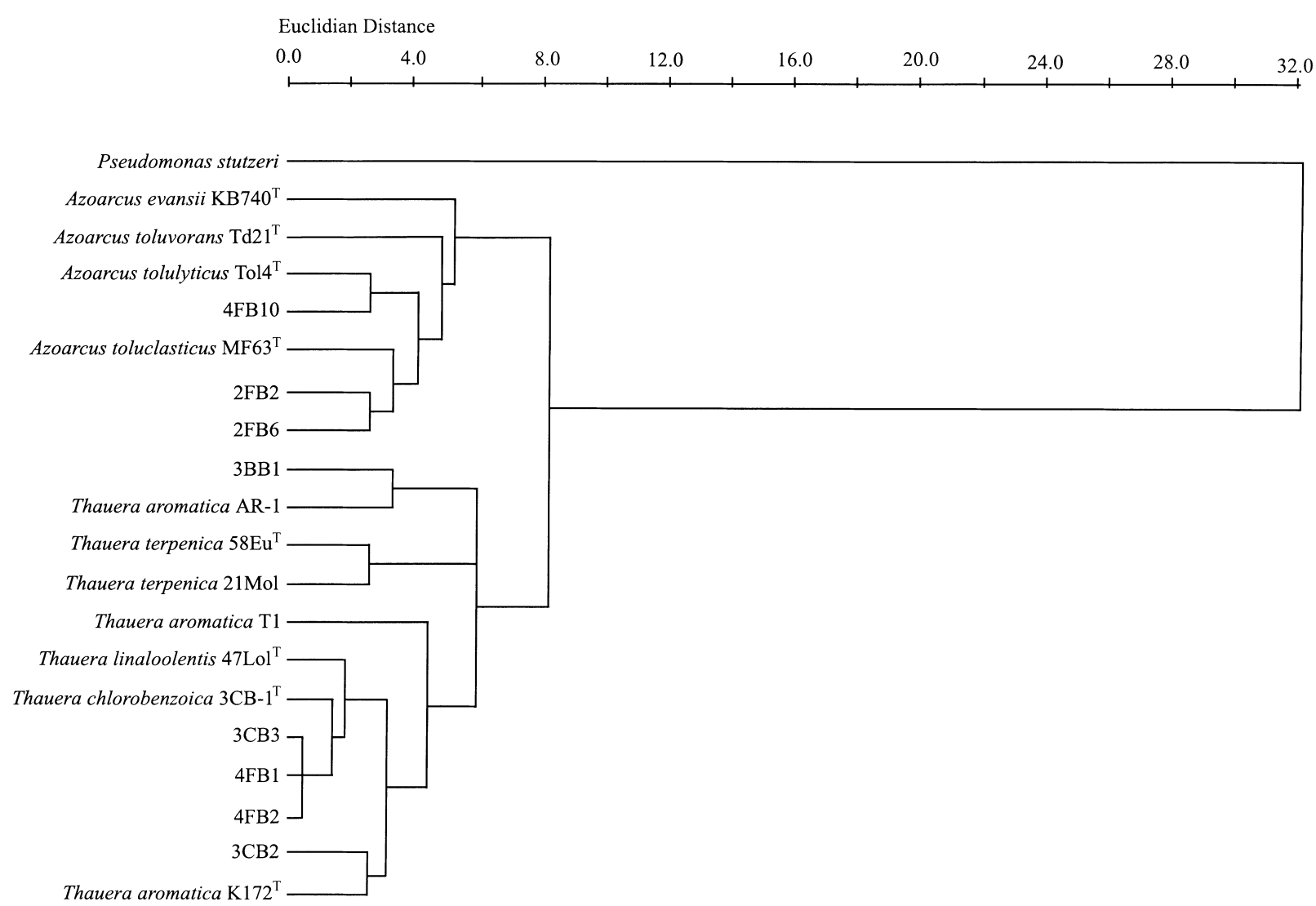

Fig. 2. Dendrogram analysis of strains of the genera Azoarcus and Thauera on the basis of cellular fatty acid analysis, with Pseudomonas stutzeri as the outgroup. Strains were grown with $10 \mathrm{mM}$ succinate and $30 \mathrm{mM}$ nitrate for $24 \mathrm{~h}$ under denitrifying conditions. 
Table 2. Fatty acid composition of strains in the genera Thauera and Azoarcus

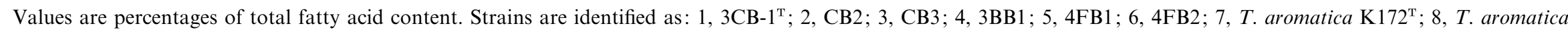

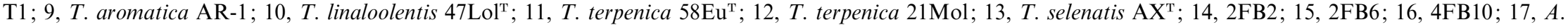

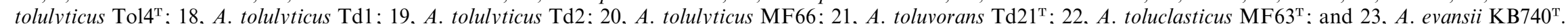
Cells were cultivated with $10 \mathrm{mM}$ succinate and $30 \mathrm{mM}$ nitrate under anaerobic conditions for $24 \mathrm{~h}$ at $30^{\circ} \mathrm{C}$. T. selenatis was cultivated in the same denitrifying medium but with the addition of $5 \times$ vitamin solution.

\begin{tabular}{|c|c|c|c|c|c|c|c|c|c|c|c|c|c|c|c|c|c|c|c|c|c|c|c|}
\hline Fatty acid & 1 & 2 & 3 & 4 & 5 & 6 & 7 & 8 & 9 & 10 & 11 & 12 & 13 & 14 & 15 & 16 & 17 & 18 & 19 & 20 & 21 & 22 & 23 \\
\hline $10: 0$ & $0 \cdot 0$ & $0 \cdot 5$ & $0 \cdot 4$ & $0 \cdot 0$ & $0 \cdot 4$ & $0 \cdot 4$ & $0 \cdot 0$ & $0 \cdot 4$ & $0 \cdot 5$ & $0 \cdot 3$ & $0 \cdot 2$ & $0 \cdot 3$ & $0 \cdot 0$ & $0 \cdot 6$ & $0 \cdot 4$ & $0 \cdot 4$ & $0 \cdot 6$ & $0 \cdot 5$ & $0 \cdot 7$ & $0 \cdot 6$ & $0 \cdot 5$ & $0 \cdot 5$ & $0 \cdot 8$ \\
\hline 10:0 3-OH & $5 \cdot 5$ & $5 \cdot 2$ & $4 \cdot 9$ & $4 \cdot 9$ & $4 \cdot 8$ & $5 \cdot 0$ & $5 \cdot 5$ & $6 \cdot 3$ & $6 \cdot 2$ & $4 \cdot 5$ & $3 \cdot 8$ & $4 \cdot 2$ & $5 \cdot 0$ & $5 \cdot 8$ & $4 \cdot 2$ & $4 \cdot 8$ & $6 \cdot 6$ & $6 \cdot 0$ & $6 \cdot 2$ & $6 \cdot 6$ & $3 \cdot 1$ & $5 \cdot 5$ & $8 \cdot 0$ \\
\hline $12: 0$ & $5 \cdot 5$ & $6 \cdot 3$ & $5 \cdot 1$ & $6 \cdot 4$ & $5 \cdot 1$ & $5 \cdot 3$ & $5 \cdot 7$ & $6 \cdot 0$ & $6 \cdot 4$ & $5 \cdot 2$ & $5 \cdot 0$ & $4 \cdot 7$ & $7 \cdot 8$ & $6 \cdot 0$ & $6 \cdot 2$ & $6 \cdot 5$ & $7 \cdot 1$ & $7 \cdot 0$ & $7 \cdot 0$ & $7 \cdot 1$ & $4 \cdot 7$ & $5 \cdot 6$ & 6.9 \\
\hline $12: 03-\mathrm{OH}$ & $0 \cdot 0$ & $0 \cdot 0$ & $0 \cdot 0$ & $0 \cdot 0$ & $0 \cdot 0$ & $0 \cdot 0$ & $0 \cdot 0$ & $0 \cdot 0$ & $0 \cdot 0$ & $0 \cdot 0$ & $0 \cdot 0$ & $0 \cdot 0$ & $3 \cdot 6$ & $0 \cdot 6$ & $0 \cdot 7$ & $0 \cdot 8$ & $0 \cdot 0$ & $0 \cdot 0$ & $0 \cdot 0$ & $0 \cdot 0$ & $0 \cdot 0$ & $0 \cdot 0$ & $0 \cdot 0$ \\
\hline $14: 0$ & $0 \cdot 0$ & $0 \cdot 6$ & $0 \cdot 7$ & $0 \cdot 9$ & $0 \cdot 6$ & $0 \cdot 6$ & $0 \cdot 0$ & $0 \cdot 8$ & $0 \cdot 6$ & $0 \cdot 2$ & $0 \cdot 4$ & $0 \cdot 5$ & $0 \cdot 0$ & $0 \cdot 0$ & $0 \cdot 0$ & $0 \cdot 0$ & $0 \cdot 8$ & $1 \cdot 0$ & $1 \cdot 0$ & $1 \cdot 3$ & $0 \cdot 8$ & $0 \cdot 4$ & $0 \cdot 8$ \\
\hline $16: 1 \omega 7 c$ & $45 \cdot 7$ & $46 \cdot 7$ & $45 \cdot 6$ & $49 \cdot 3$ & $45 \cdot 6$ & $46 \cdot 4$ & $46 \cdot 2$ & $42 \cdot 5$ & $42 \cdot 6$ & $45 \cdot 6$ & $49 \cdot 5$ & $48 \cdot 5$ & $40 \cdot 9$ & $49 \cdot 6$ & $49 \cdot 9$ & $50 \cdot 9$ & $52 \cdot 7$ & $52 \cdot 8$ & $51 \cdot 2$ & $52 \cdot 5$ & $51 \cdot 0$ & $51 \cdot 8$ & $46 \cdot 9$ \\
\hline $16: 1 \omega 5 c$ & $0 \cdot 5$ & $1 \cdot 0$ & $0 \cdot 9$ & $1 \cdot 1$ & $0 \cdot 9$ & $0 \cdot 9$ & $1 \cdot 3$ & $0 \cdot 6$ & $0 \cdot 7$ & 0.6 & $0 \cdot 8$ & $0 \cdot 6$ & $0 \cdot 0$ & 0.7 & $0 \cdot 7$ & $0 \cdot 6$ & $0 \cdot 5$ & $0 \cdot 4$ & $0 \cdot 0$ & $0 \cdot 0$ & $0 \cdot 0$ & $0 \cdot 8$ & $0 \cdot 5$ \\
\hline $16: 0$ & $28 \cdot 7$ & $25 \cdot 3$ & $28 \cdot 5$ & $24 \cdot 9$ & $28 \cdot 6$ & $28 \cdot 3$ & $25 \cdot 1$ & $31 \cdot 5$ & $26 \cdot 2$ & $28 \cdot 5$ & $23 \cdot 8$ & $25 \cdot 2$ & $24 \cdot 6$ & $26 \cdot 7$ & $26 \cdot 7$ & $28 \cdot 1$ & $25 \cdot 4$ & $27 \cdot 5$ & $26 \cdot 8$ & $26 \cdot 7$ & $29 \cdot 7$ & $25 \cdot 6$ & $27 \cdot 4$ \\
\hline $17: 0$ cyclo & $0 \cdot 7$ & $2 \cdot 1$ & $0 \cdot 9$ & $0 \cdot 9$ & $0 \cdot 9$ & $0 \cdot 9$ & $1 \cdot 7$ & $1 \cdot 5$ & $0 \cdot 0$ & $0 \cdot 0$ & $0 \cdot 0$ & $0 \cdot 0$ & $0 \cdot 0$ & $0 \cdot 7$ & $0 \cdot 9$ & $1 \cdot 1$ & $0 \cdot 0$ & $0 \cdot 0$ & $0 \cdot 0$ & $0 \cdot 0$ & $0 \cdot 0$ & $0 \cdot 0$ & $0 \cdot 0$ \\
\hline $18: 1 \omega 7 c / \omega 9 t / \omega 12 t$ & $13 \cdot 4$ & $12 \cdot 3$ & $13 \cdot 0$ & $10 \cdot 8$ & $12 \cdot 8$ & $12 \cdot 4$ & $14 \cdot 5$ & $10 \cdot 3$ & $17 \cdot 1$ & $14 \cdot 6$ & $15 \cdot 7$ & $14 \cdot 9$ & $17 \cdot 6$ & $9 \cdot 5$ & $9 \cdot 1$ & $6 \cdot 2$ & $6 \cdot 8$ & $4 \cdot 8$ & $6 \cdot 7$ & $5 \cdot 3$ & $10 \cdot 3$ & $9 \cdot 3$ & $8 \cdot 2$ \\
\hline $18: 1 \omega 5 c$ & $0 \cdot 0$ & $0 \cdot 0$ & $0 \cdot 0$ & $0 \cdot 0$ & $0 \cdot 0$ & $0 \cdot 0$ & $0 \cdot 0$ & $0 \cdot 0$ & $0 \cdot 0$ & $0 \cdot 2$ & $0 \cdot 2$ & $0 \cdot 0$ & $0 \cdot 0$ & $0 \cdot 0$ & $0 \cdot 0$ & $0 \cdot 0$ & $0 \cdot 0$ & $0 \cdot 0$ & $0 \cdot 0$ & $0 \cdot 0$ & $0 \cdot 0$ & $0 \cdot 0$ & $0 \cdot 0$ \\
\hline $18: 0$ & $0 \cdot 0$ & $0 \cdot 0$ & $0 \cdot 0$ & $0 \cdot 0$ & $0 \cdot 4$ & $0 \cdot 2$ & $0 \cdot 0$ & $0 \cdot 0$ & $0 \cdot 0$ & $0 \cdot 2$ & $0 \cdot 2$ & $0 \cdot 4$ & $1 \cdot 2$ & $0 \cdot 0$ & $0 \cdot 0$ & $0 \cdot 1$ & $0 \cdot 0$ & $0 \cdot 0$ & $0 \cdot 0$ & $0 \cdot 0$ & $0 \cdot 0$ & $0 \cdot 0$ & $0 \cdot 0$ \\
\hline
\end{tabular}


Table 3. Comparison of the characteristics of halobenzoate-degrading isolates and the species in the genus Azoarcus

Data were obtained from this study and the following sources: Zhou et al. (1995) and Song et al. (1999) (A. tolulyticus Tol4 ${ }^{\mathrm{T}}$, A. toluvorans $\mathrm{Td}^{2} 1^{\mathrm{T}}$ and A. toluclasticus MF63 $)$; Anders et al. (1995) (A evansii KB740 $)$; Springer et al. (1998) (A anaerobius LuFRes1 ${ }^{\mathrm{T}}$ ); and Reinhold-Hurek et al. (1993) (A. indigens VB32 ${ }^{\mathrm{T}}$. Growth is scored as + (growth) or - (no growth). ND, Not determined. Cells of all strains listed are motile rods.

\begin{tabular}{|c|c|c|c|c|c|c|c|c|c|}
\hline \multirow[t]{2}{*}{ Characteristic } & \multicolumn{4}{|c|}{ A. tollulyticus } & \multirow{2}{*}{$\begin{array}{l}\text { A. toluvorans } \\
{ }_{\mathrm{T} d 21^{\mathrm{T}}}\end{array}$} & \multirow{2}{*}{$\begin{array}{l}\text { A. toluclasticus } \\
\text { MF63 }^{\mathrm{T}}\end{array}$} & \multirow{2}{*}{$\begin{array}{l}\text { A. evansii } \\
\text { KB } 740^{\mathrm{T}}\end{array}$} & \multirow{2}{*}{$\begin{array}{l}\text { A. anaerobius } \\
\text { LuFRes1 }^{T}\end{array}$} & \multirow{2}{*}{$\begin{array}{l}\text { A. indigens } \\
\mathbf{V B 3 2}^{\mathrm{T}}\end{array}$} \\
\hline & $2 \mathrm{FB} 2$ & 2FB6 & $4 F B 10$ & Tol $^{\mathrm{T}}$ & & & & & \\
\hline Cell size $(\mu \mathrm{m})$ & $1 \cdot 6-3 \cdot 3 \times 0.8$ & $1-4 \times 0.93$ & $1.5-4 \times 0.85$ & $1.4-2.1 \times 0.78$ & $1.3-2.1 \times 0.77$ & $1.5-2.0 \times 0.75$ & $1.5-3.0 \times 0.7$ & $2 \cdot 7-3 \cdot 3 \times 1 \cdot 5$ & $2.0-4.0 \times 0.6$ \\
\hline Flagellation & Monotrichous & Monotrichous & Monotrichous & Monotrichous & Monotrichous & Monotrichous & Monotrichous & ND & Monotrichous \\
\hline Catalase/oxidase & $+1+$ & $+/+$ & $+1+$ & $+/+$ & $+1+$ & $+1+$ & $+1+$ & $-1+$ & $+1+$ \\
\hline $\begin{array}{l}\mathrm{G}+\mathrm{C} \text { content }(\mathrm{mol} \%) \\
\text { Optimum } \mathrm{pH} \text { for growth }\end{array}$ & $66 \cdot 1$ & $64 \cdot 0$ & $66 \cdot 0$ & $66 \cdot 9$ & 67.8 & $67 \cdot 3$ & 67.5 & 66.5 & $66 \cdot 6$ \\
\hline $\begin{array}{l}\text { Optimum } \mathrm{pH} \text { for growth } \\
\text { Optimum temperature for growth }\left({ }^{\circ} \mathrm{C}\right)\end{array}$ & $\begin{array}{l}8.0 \\
37\end{array}$ & $7 \cdot 5$ & $\begin{array}{c}7 \cdot 0 \\
30\end{array}$ & $\mathrm{ND}$ & $\mathrm{ND}$ & $\mathrm{ND}$ & $\begin{array}{c}7.8 \\
28.37\end{array}$ & $7 \cdot 2$ & $\begin{array}{l}7 \cdot 0-7 \cdot 5 \\
40\end{array}$ \\
\hline Electron acceptors & $\mathrm{NO}_{3}^{-1}, \mathrm{O}_{2}$ & $\mathrm{NO}_{3}^{-50}, \mathrm{O}_{2}$ & $\mathrm{NO}_{3}^{-}, \mathrm{O}_{2}$ & $\mathrm{NO}_{3}^{-1}, \mathrm{O}_{2}$ & $\mathrm{NO}_{3}^{-}, \mathrm{O}_{2}$ & $\mathrm{NO}_{3}^{-}, \mathrm{O}_{2}$ & $\begin{array}{l}28-37 \\
\mathrm{NO}_{3}^{-}, \mathrm{O}_{2}\end{array}$ & $\mathrm{NO}^{20-32}$ & ${ }^{40}$ \\
\hline $\begin{array}{l}\text { Use of sole carbon substrate for growth under } \\
\text { aerobic }\left(\mathrm{O}_{2}\right) \text { /denitrifying }\left(\mathrm{NO}_{3}^{-}\right) \text {conditions: }\end{array}$ & $\mathrm{O}_{2} / \mathrm{NO}_{3}^{-}$ & $\mathrm{O}_{2} / \mathrm{NO}_{3}^{-}$ & $\mathrm{O}_{2} / \mathrm{NO}_{3}^{-}$ & $\mathrm{O}_{2} / \mathrm{NO}_{3}^{-}$ & $\mathrm{O}_{2} / \mathrm{NO}_{3}^{-}$ & $\mathrm{O}_{2} / \mathrm{NO}_{3}^{-}$ & $\mathrm{O}_{2} / \mathrm{NO}_{3}^{-}$ & $\mathrm{NO}_{3}^{-}$ & $\begin{array}{ll}\mathrm{O}_{2} \\
\mathrm{O}_{2}\end{array}$ \\
\hline Acetate & $+1+$ & $+1+$ & $+1+$ & $+1+$ & $+/+$ & $+1+$ & $+1+$ & + & + \\
\hline Adipate & $+/+$ & $+1+$ & $+/+$ & ND & $\mathrm{ND}$ & ND & $-/ \mathrm{ND}$ & - & - \\
\hline $\begin{array}{l}\text { D-Alanine } \\
\text { LAsparagine }\end{array}$ & $+1+$ & $+1+$ & $\begin{array}{l}+1+ \\
+1+\end{array}$ & ND & ND & ND & $\mathrm{ND}$ & ND & - \\
\hline $\begin{array}{l}\text { LAsparagine } \\
\text { Betaine }\end{array}$ & $\begin{array}{l}+1+ \\
+1+ \\
+1+2\end{array}$ & $\begin{array}{l}+1+ \\
+1+\end{array}$ & $\begin{array}{l}+1+ \\
+1+\end{array}$ & ND & ND & ND & $+/ \mathrm{ND}$ & ND & - \\
\hline Butyrate & $\begin{array}{l}71+ \\
+1+\end{array}$ & $\begin{array}{l}71+ \\
+1+\end{array}$ & $\begin{array}{l}71+ \\
+1+\end{array}$ & $\begin{array}{l}\mathrm{ND} \\
+1+\end{array}$ & $\begin{array}{c}\mathrm{ND} \\
+1+\end{array}$ & ND & $\mathrm{ND}$ & ND & - \\
\hline Caproate & $+1+$ & $+1+$ & $\begin{array}{l}1+1+ \\
+1+2\end{array}$ & $\begin{array}{l}1 / 4 \\
+1+\end{array}$ & $\begin{array}{l}1+1+ \\
+1+\end{array}$ & $\begin{array}{l}+1+ \\
-1-\end{array}$ & $+2 / \mathrm{ND}$ & ND & ${ }_{-}^{+}$ \\
\hline D-Fructose & $+1+$ & $+1+$ & $+1+$ & $+1+$ & $-1+$ & $+1+$ & $+/ \mathrm{ND}$ & - & - \\
\hline D-Glucose & $+1+$ & $+1+$ & $+1+$ & $+1+$ & $-1-$ & $+1+$ & $\mathrm{ND} /+$ & - & - \\
\hline Glutamate & $+1+$ & $+1+$ & $+1+$ & ND & ND & ND & $+/ \mathrm{ND}$ & ND & + \\
\hline Lactose & $+1+$ & $+1+$ & $+1+$ & ND & ND & ND & ND & ND & - \\
\hline Malate & $+/+$ & $+1+$ & $+1+$ & ND & ND & ND & $+/ \mathrm{ND}$ & - & + \\
\hline Ornithine & $+/+$ & $+/+$ & $+1+$ & ND & ND & ND & $+/ \mathrm{ND}$ & ND & - \\
\hline Pyruvate & $+1+$ & $+/+$ & $+1+$ & +/t & +/+ & +/+ & $+/ \mathrm{ND}$ & + & + \\
\hline Succinate & $+/+$ & $+1+$ & $+1+$ & $+1+$ & $+/+$ & $+/+$ & $+/ \mathrm{ND}$ & + & + \\
\hline Valerate & $+/+$ & +/+ & $+1-$ & $-1-$ & $+/-$ & $-1-$ & ND & + & ND \\
\hline
\end{tabular}




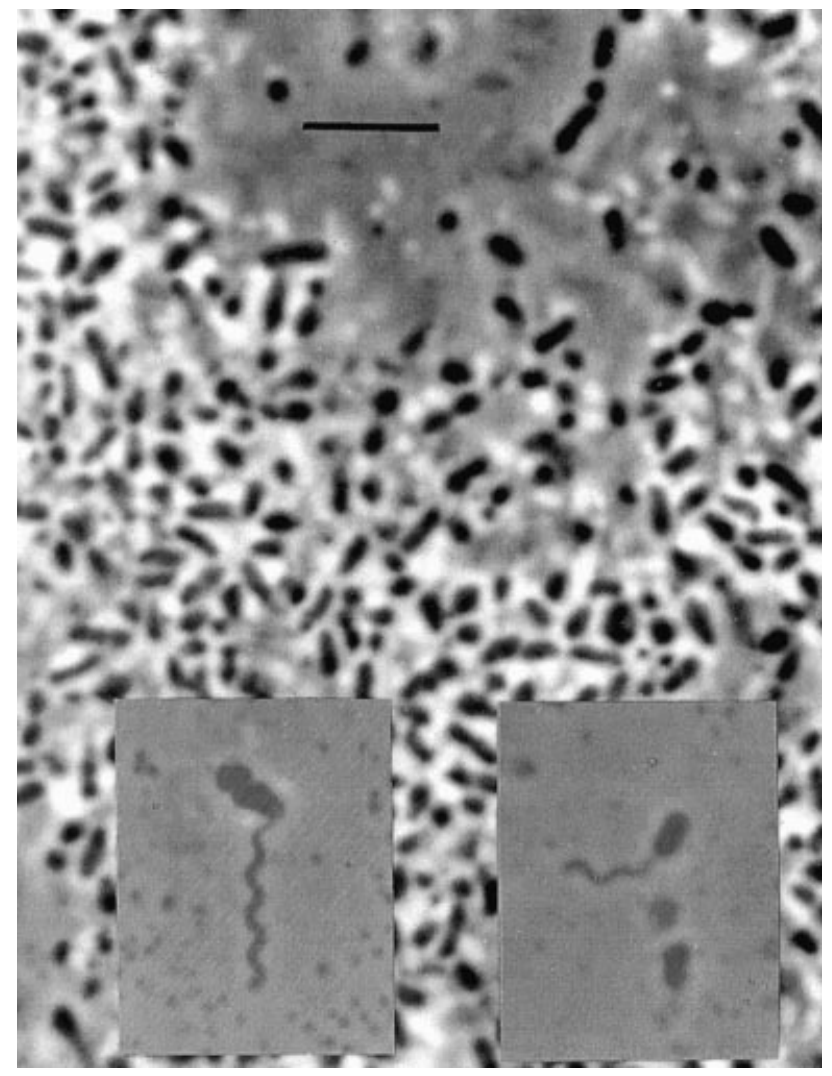

Fig. 3. Azoarcus sp. strain 2FB6. Cells were grown in Bacto Tryptic Soy broth with $1 \%$ Difco yeast extract for $24 \mathrm{~h}$ at $28^{\circ} \mathrm{C}$. Insets, cells with single polar flagella (stained using Leifson's method). Bar, $5 \mu \mathrm{m}$.

The profiles of cellular fatty acids of each strain and the species of the genera Azoarcus and Thauera are compared in Table 2 . The predominant fatty acids of the genus Thauera are 10:0 3-OH (3.8-6.3\%), 12:0 $(4 \cdot 7-7 \cdot 8 \%), \quad 16: 1 \omega 7 c \quad(40.9-49 \cdot 5 \%), \quad 16: 0 \quad(23.8-$ $31 \cdot 5 \%)$ and $18: 1(10 \cdot 3-17 \cdot 6 \%)$, and members of the genus Azoarcus have 10:0 3-OH (3.1-8.0\%), 12:0 $(4 \cdot 7-7 \cdot 1 \%), \quad 16: 1 \omega 7 c \quad(46 \cdot 9-52 \cdot 8 \%), \quad 16: 0 \quad(25 \cdot 4-$ $28 \cdot 1 \%)$ and $18: 1(4 \cdot 8-10 \cdot 3 \%)$ fatty acids after growth under denitrifying conditions. The strains and species in the genus Thauera had a higher proportion of 18:1 fatty acid and a lower proportion of $16: 1 \omega 7 c$ than those of the genus Azoarcus. Halobenzoate-degrading strains and the strains of $T$. aromatica had 17:0 cyclo $(0 \cdot 7-2 \cdot 1 \%)$ fatty acids in their cellular profiles, except in the case of strain AR-1, which did not have a detectable amount of this fatty acid.

\section{Morphological and physiological characterization}

The cells of strains 2FB2, 2FB6 and 4FB10 in the genus Azoarcus are rods with dimensions of 1-4 $40 \cdot 8$ $0.93 \mu \mathrm{m}$ and are motile, each cell having a monotrichous flagellum; this is in agreement with the description of the species A. tolulyticus (Table 3). The general morphology and flagellation of strain 2FB6 are shown in Fig. 3. The mean length of the cells is $1.13 \mu \mathrm{m}$ and the mean width is $0.67 \mu \mathrm{m}$. The physiological characteristics of strains and species in the genus Azoarcus are listed in Table 3. The optimum pH and temperatures for growth were 7.0-8.0 and 30 $37^{\circ} \mathrm{C}$. Strains $2 \mathrm{FB} 2,2 \mathrm{FB} 6$ and $4 \mathrm{FB} 10$ could use $\mathrm{O}_{2}$, $\mathrm{NO}_{3}^{-}$or $\mathrm{NO}_{2}^{-}$as the electron acceptor for growth. Strains in the genus Azoarcus demonstrated versatility of growth on different sugars and with short-chain fatty acids as carbon sources (Table 3 ).

Strains 3CB2, 3CB3, 3BB1, 4FB1 and 4FB2 in the genus Thauera are short rods, with dimensions of $1 \cdot 2-2 \cdot 7 \times 0 \cdot 85-1 \mu \mathrm{m}$, and are motile with peritrichous flagella, which are characteristic of the species $T$. aromatica (Table 4) but not of the rest of the genus. The typical morphology and flagellation of strain 4FB2 are shown in Fig. 4. The mean length of the cells is $1.66 \mu \mathrm{m}$ and the mean width is $0.72 \mu \mathrm{m}$; in some complex media, they tended to form long chains. In some of the cells, inclusions were visible, using phasecontrast optics. The physiological characteristics of strains in the genus Thauera are compared in Table 4. The optimum $\mathrm{pH}$ and temperature for growth were $7 \cdot 5-8.0$ and $30-37^{\circ} \mathrm{C}$. The halobenzoate-degrading isolates were able to grow with $\mathrm{O}_{2}, \mathrm{NO}_{3}^{-}$or $\mathrm{NO}_{2}^{-}$as the electron acceptors in the presence of succinate, but not with $\mathrm{SO}_{4}^{2-}, \mathrm{SO}_{3}^{2-}, \mathrm{S}_{2} \mathrm{O}_{3}^{2-}, \mathrm{SeO}_{4}^{2-}$ or $\mathrm{SeO}_{3}^{-}$. Growth tests on various substrates showed that the strains were unable to utilize sugars but that they could grow well on short-chain fatty acids (Table 4).

The utilization of aromatic compounds under aerobic and denitrifying conditions was tested with all of the halobenzoate-degrading isolates and some strains in the genera Azoarcus and Thauera. The data on utilization of aromatic compounds under either denitrifying or aerobic conditions are listed in Table 5. All of the strains were able to utilize benzoate, phenylacetate, vanillate, 3-hydroxybenzoate, 4hydroxybenzoate, 2-fluorobenzoate and 4-fluorobenzoate. None of them could degrade phthalate, 4aminobenzoate, 2-chlorobenoate, 4-chlorobenzoate, 2-bromobenzoate, 4-bromobenzoate, 2-methylbenzoate or 4-methylbenzoate under either aerobic or denitrifying conditions. Only those strains isolated on 3-chlorobenzoate or 3-bromobenzoate were able to use 3-aminobenzoate, 3-methylbenzoate, 3-chlorobenzoate and 3-bromobenzoate under denitrifying conditions. Interestingly, T. aromatica strains $\mathrm{K} 172^{\mathrm{T}}$, T1 and AR-1 can degrade 2-fluorobenzoate and 4fluorobenzoate and strain T1 can also utilize 3chlorobenzoate and 3-bromobenzoate under denitrifying conditions. A. tolulyticus strain Tol $4^{\mathrm{T}}$ can use 2-fluorobenzoate under denitrifying conditions.

\section{Determination of DNA base composition}

The DNAs of the halobenzoate-degrading strains belonging to the genus Thauera had $\mathrm{G}+\mathrm{C}$ contents of $67 \cdot 1-69 \cdot 4 \mathrm{~mol} \%$ (Table 4 ) and the DNAs of strains 
Table 4. Comparison of the characteristics of halobenzoate-degrading isolates and the species in the genus Thauera

Data were obtained from this study and the following sources: Anders et al. (1995) and Song et al. (1998) (T. aromatica K172T); Foss \& Harder (1998) (T. linaloolentis

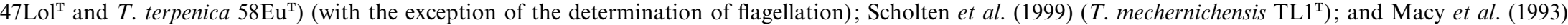

(T. selenatis $\left.\mathrm{AX}^{\mathrm{T}}\right)$. Growth is scored as + (growth) or - (no growth). ND, Not determined. All strains listed are catalase- and oxidase-positive.

\begin{tabular}{|c|c|c|c|c|c|c|c|c|c|c|c|}
\hline \multirow[t]{2}{*}{ Characteristic } & \multicolumn{4}{|c|}{ T. chlorobenzoica } & \multicolumn{3}{|c|}{ T. aromatica } & \multirow{2}{*}{$\begin{array}{l}\text { T. linaloolentis } \\
47 \mathrm{Lol}^{\mathrm{T}}\end{array}$} & \multirow{2}{*}{$\begin{array}{l}\text { T. terpenica } \\
{\mathbf{5 8 E u ^ { \mathrm { T } }}}\end{array}$} & \multirow{2}{*}{$\begin{array}{l}\text { T. mechernichensis } \\
\text { TL1 }^{\mathrm{T}}\end{array}$} & \multirow{2}{*}{$\begin{array}{l}\text { T. selenatis } \\
\mathbf{A X}^{\mathrm{T}}\end{array}$} \\
\hline & $3 \mathrm{CB}-\mathbf{1}^{\mathrm{T}}$ & 4FB1 & $4 \mathrm{FB} 2$ & 3BB1 & $3 \mathrm{CB} 2$ & 3CB3 & $\mathrm{K} 172^{\mathrm{T}}$ & & & & \\
\hline Cell morphology & Rods & Rods & Rods & Rods & Rods & Rods & Coccoid rods & Rods & Rods & Short rods & Rods \\
\hline Cell size $(\mu \mathrm{m})$ & $3 \cdot 0-3 \cdot 7$ & $1.5-2.7 \times 0.85$ & $1.5-2.5 \times 0.87$ & $1.2-1.7 \times 0.97$ & $1 \cdot 6-2 \cdot 7 \times 1$ & $1.6-2.7 \times 0.88$ & $1 \cdot 0-2.5 \times 1 \cdot 0$ & $1.4-2.7 \times 0.7$ & $1 \cdot 6-2 \cdot 2 \times 0 \cdot 9$ & $1.5-2.0 \times 0.75$ & $1.4 \times 0.56$ \\
\hline Motility & + & + & + & + & + & + & + & - & + & + & + \\
\hline Flagellation & Peritrichous & Peritrichous & Peritrichous & Peritrichous & Peritrichous & Peritrichous & Peritrichous & None & Monotrichous & Monotrichous & Monotrichous \\
\hline $\mathrm{G}+\mathrm{C}$ content $(\mathrm{mol} \%)$ & $68 \cdot 6$ & $69 \cdot 3$ & $69 \cdot 4$ & ND & $67 \cdot 1$ & $67 \cdot 1$ & 67.0 & $65 \cdot 6$ & $64 \cdot 2$ & $65 \cdot 0$ & $66 \cdot 0$ \\
\hline Optimum pH for growth & $7 \cdot 5-8 \cdot 0$ & $8 \cdot 0$ & $8 \cdot 0$ & 7.5 & $8 \cdot 0$ & $8 \cdot 0$ & $7 \cdot 0-7 \cdot 4$ & $7 \cdot 0-7 \cdot 3$ & $7 \cdot 9-8 \cdot 8$ & ND & $8 \cdot 0$ \\
\hline Optimum temperature for growth $\left({ }^{\circ} \mathrm{C}\right)$ & 30 & 37 & 37 & 30 & 37 & 37 & 28 & 32 & 32 & 40 & $25-30$ \\
\hline Electron acceptors & $\mathrm{NO}_{3}^{-}, \mathrm{O}_{2}$ & $\mathrm{NO}_{3}^{-}, \mathrm{O}_{2}$ & $\mathrm{NO}_{3}^{-}, \mathrm{O}_{2}$ & $\mathrm{NO}_{3}^{-}, \mathrm{O}_{2}$ & $\mathrm{NO}_{3}^{-}, \mathrm{O}_{2}$ & $\mathrm{NO}_{3}^{-}, \mathrm{O}_{2}$ & $\mathrm{NO}_{3}^{-}, \mathrm{O}_{2}$ & $\mathrm{NO}_{3}^{-}, \mathrm{O}_{2}$ & $\mathrm{NO}_{3}^{-}, \mathrm{O}_{2}$ & $\mathrm{NO}_{3}^{-}, \mathrm{O}_{2}$ & $\mathrm{NO}_{3}^{-}, \mathrm{O}_{2}, \mathrm{Se}(\mathrm{VI}), \mathrm{Se}(\mathrm{IV})$ \\
\hline $\begin{array}{l}\text { Use of sole carbon substrates for growth } \\
\text { under aerobic }\left(\mathrm{O}_{2}\right) / \text { denitrifying }\left(\mathrm{NO}_{3}^{-}\right) \text {conditions: }\end{array}$ & $\mathrm{O}_{2}, \mathrm{NO}_{3}^{-}$ & $\mathrm{O}_{2}, \mathrm{NO}_{3}^{-}$ & $\mathrm{O}_{2}, \mathrm{NO}_{3}^{-}$ & $\mathrm{O}_{2}, \mathrm{NO}_{3}^{-}$ & $\mathrm{O}_{2}, \mathrm{NO}_{3}^{-}$ & $\mathrm{O}_{2}, \mathrm{NO}_{3}^{-}$ & $\mathrm{O}_{2}, \mathrm{NO}_{3}^{-}$ & $\mathrm{NO}_{3}^{-}$ & $\mathrm{NO}_{3}^{-}$ & $\mathrm{O}_{2}, \mathrm{NO}_{3}^{-}$ & $\mathrm{O}_{2}$ \\
\hline Acetate & $+1+$ & $+/+$ & $+/+$ & $+/+$ & $+/+$ & $+1+$ & $+/+$ & + & + & ND & + \\
\hline Adipate & $-1-$ & $+1+$ & $+1+$ & $+/+$ & $-1+$ & $-1-$ & $+1+$ & ND & ND & $\mathrm{ND}$ & ND \\
\hline D-Alanine & $-1-$ & $-1-$ & $-1-$ & $-1-$ & $-1+$ & $+1-$ & $-1-$ & ND & ND & ND & + \\
\hline L-Asparagine & $-1-$ & $-1-$ & $-1-$ & $+/+$ & $-1+$ & $+1+$ & $-1-$ & ND & ND & $\mathrm{ND}$ & + \\
\hline Betaine & $-1-$ & $-1-$ & $-1-$ & $-1-$ & $-1-$ & $-1+$ & $-1-$ & ND & ND & ND & ND \\
\hline Butyrate & $+1+$ & $+/+$ & $+/+$ & $+/+$ & $+1+$ & $+1+$ & $+1+$ & + & + & ND & ND \\
\hline Caproate & $-1+$ & $+1+$ & $+1+$ & $+1+$ & $-1+$ & $+1+$ & $-1-$ & ND & ND & ND & ND \\
\hline Ethanol & $-1+$ & $-1+$ & $-1+$ & $-1-$ & $-1+$ & $-1+$ & $+1+$ & + & - & ND & ND \\
\hline D-Fructose & $-1-$ & $-1-$ & $-1-$ & $-1-$ & $-1-$ & $-1-$ & $-1-$ & - & - & ND & + \\
\hline D-Glucose & $-1-$ & $-1-$ & $-1-$ & $-1-$ & $-1-$ & $-1-$ & $-1-$ & - & - & ND & + \\
\hline Glutamate & $+1+$ & $+1+$ & $+1+$ & $+1+$ & $+1+$ & $+1+$ & $+1+$ & + & + & ND & + \\
\hline Lactose & $-1-$ & $-1-$ & $-1-$ & $-1-$ & $-1-$ & $-1-$ & $-1-$ & ND & ND & ND & + \\
\hline Malate & $+1+$ & $+1+$ & $+1+$ & $+1+$ & $+1+$ & $+1+$ & $+1+$ & + & + & ND & ND \\
\hline Ornithine & $-1+$ & $+1+$ & $+/+$ & $+1+$ & $+1+$ & $+1+$ & $-1+$ & ND & ND & ND & ND \\
\hline Pyruvate & $+1+$ & $+1+$ & $+1+$ & $+1+$ & $+1+$ & $+1+$ & $+1+$ & + & + & ND & + \\
\hline Succinate & $+1+$ & $+1+$ & $+/+$ & $+1+$ & $+/+$ & $+1+$ & $+1+$ & + & + & $\mathrm{ND}$ & + \\
\hline Valerate & $-1-$ & $+1-$ & $+1+$ & $+1-$ & $-1+$ & $+/+$ & $+1+$ & ND & ND & ND & ND \\
\hline
\end{tabular}




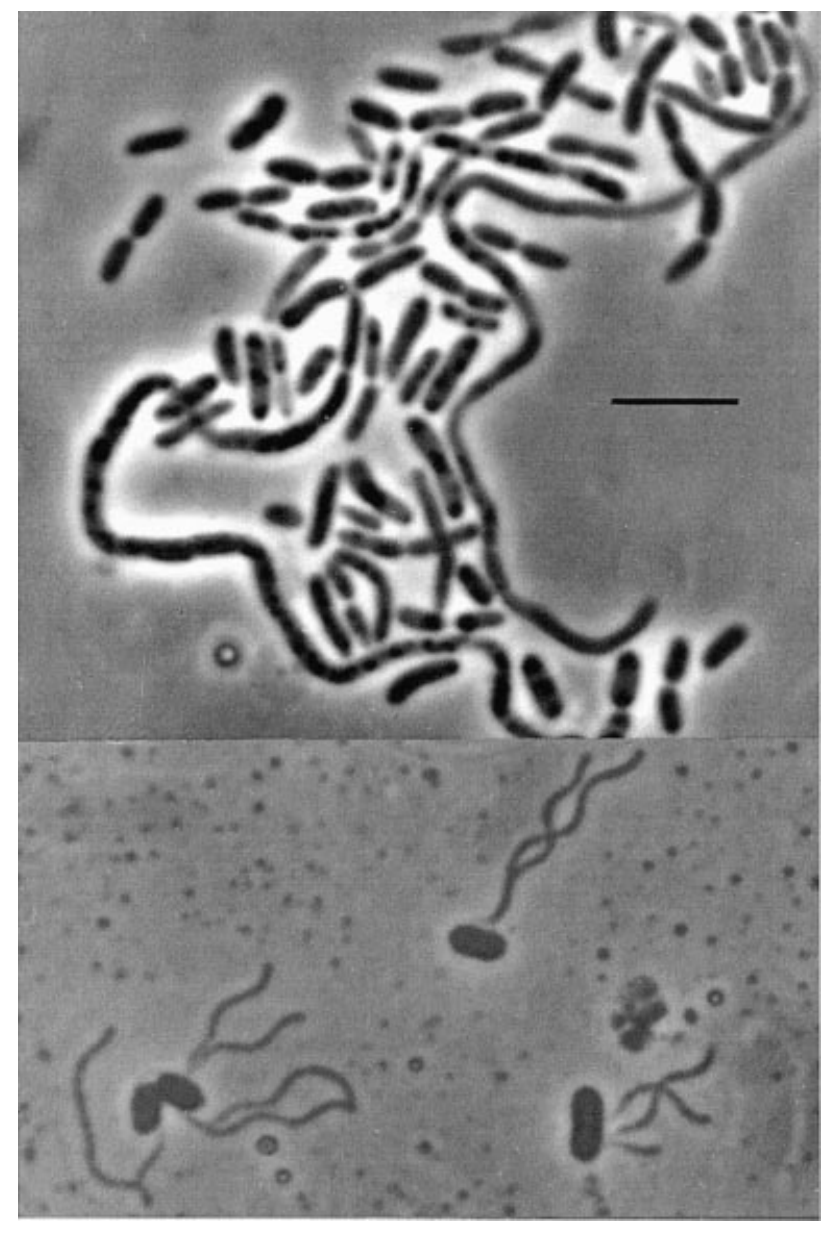

Fig. 4. Thauera sp. strain 4FB2. Cells were grown in Bacto brain-heart infusion for $24 \mathrm{~h}$ at $28^{\circ} \mathrm{C}$. Inclusions can be seen in some of the cells. Bottom, cells with 'degenerately peritrichous' flagella (stained using Leifson's method). Bar, $5 \mu \mathrm{m}$. from the genus Azoarcus had $\mathrm{G}+\mathrm{C}$ contents of $64 \cdot 0-66 \cdot 1 \mathrm{~mol} \%$ (Table 3 ).

\section{DNA-DNA hybridization}

Strains 2FB2, 2FB6 and 4FB10 belonging to the genus Azoarcus shared 80-91\% DNA similarity with $A$. tolulyticus strain Tol4 ${ }^{\mathrm{T}}$, but only $18-48 \%$ DNA similarity with the type strains of $A$. toluvorans and $A$. toluclasticus (Table 6). The polyphasic classification is in agreement with the placement of these strains into the species $A$. tolulyticus. Thus, strains 2FB2, 2FB6 and 4FB10 are new strains of $A$. tolulyticus (based on the definition specifying that there must be DNA similarity of more than $70 \%$ between strains of the same species; Wayne et al., 1987) with the capacity to degrade fluorinated benzoates under denitrifying conditions.

In contrast, strains $3 \mathrm{CB} 2,3 \mathrm{CB} 3,4 \mathrm{FB} 1$ and $4 \mathrm{FB} 2 \mathrm{had}$ less than $70 \%$ DNA similarity to strains $\mathrm{K} 172^{\mathrm{T}}$ and T1 of $T$. aromatica, but they shared more than $70 \%$ DNA similarity with $T$. aromatica strain AR-1 (Table 6). $T$. aromatica genomovar chlorobenzoica strain $3 \mathrm{CB}-1^{\mathrm{T}}$ showed more than $70 \%$ DNA similarity to strains 4FB1 and 4FB2 and about 50\% similarity to strains 3CB2 and 3CB3 (Table 6). In addition, the species $T$. linaloolentis and $T$. terpenica shared only about $30 \%$ DNA similarity with strain 4FB1 and the species $T$. selenatis had $20 \%$ DNA similarity to strains 3CB2, 3CB3, 4FB1 and 4FB2 (Table 6). Interestingly, $T$. mechernichensis shared less than $20 \%$ DNA similarity with strains $3 \mathrm{CB}-1^{\mathrm{T}}, 3 \mathrm{CB} 2$ and $4 \mathrm{FB} 1$, although they showed 16S rRNA sequence similarity of more than $98 \%$.

Three-dimensional representation of the strains in the

Table 5. Utilization of aromatic compounds by strains in the genera Azoarcus and Thauera

A dense cell suspension was incubated at $30^{\circ} \mathrm{C}$ for $7 \mathrm{~d}$ after feeding with $200 \mu \mathrm{M}$ substrate. + , Complete loss of substrate; - , less than $10 \%$ consumption of substrate; ND, not determined. Utilization under aerobic/denitrifying conditions is indicated (i.e. $+/-$ indicates that a compound is used under aerobic conditions but not under denitrifying conditions). Positive results were obtained with all strains for the utilization of benzoate and phenylacetate under both aerobic and denitrifying conditions. Negative results were obtained with all strains for the utilization of the following compounds under both aerobic and denitrifying conditions: phthalate, 4-aminobenzoate, 2-chlorobenzoate, 4-chlorobenzoate, 2-bromobenzoate, 4-bromobenzoate, 2-methylbenzoate, 4-methylbenzoate.

\begin{tabular}{|c|c|c|c|c|c|c|c|c|c|c|c|c|c|}
\hline Compound & $3 \mathrm{CB}-1^{\mathrm{T}}$ & $3 \mathrm{CB} 2$ & $3 \mathrm{CB} 3$ & 3BB1 & 4FB1 & 4FB2 & $\mathrm{K} 172^{\mathrm{T}}$ & T1 & AR-1 & 2FB2 & 2FB6 & 4FB10 & Tol4 $^{\mathrm{T}}$ \\
\hline Phenol & $-1-$ & $-1-$ & $-1-$ & $-1-$ & $-1-$ & $-1-$ & $-/+$ & $-1-$ & $-1-$ & $-/+$ & $-1-$ & $-1-$ & $-1-$ \\
\hline Toluene & $-1-$ & $-1-$ & $-1+$ & $-1-$ & $-1-$ & $-1-$ & $-/+$ & $-/+$ & $\mathrm{ND} / \mathrm{ND}$ & $\mathrm{ND} / \mathrm{ND}$ & $\mathrm{ND} / \mathrm{ND}$ & $\mathrm{ND} / \mathrm{ND}$ & $+/+$ \\
\hline Vanillate & $+/+$ & $+/+$ & $+1+$ & $+/+$ & $+1+$ & $+/+$ & $+/+$ & $+1+$ & $+1-$ & $-1-$ & $-1-$ & $-/+$ & $-1-$ \\
\hline 3-Aminobenzoate & $-/+$ & $-1+$ & $-1+$ & $-1+$ & $-1+$ & $-1+$ & $-1+$ & $-1+$ & $-1-$ & $-1-$ & $-1-$ & $-1-$ & $-1-$ \\
\hline 2-Hydroxybenzoate & $-1-$ & $-1-$ & $+1-$ & $+1-$ & $+1-$ & $-1-$ & $-1+$ & $-1-$ & $\mathrm{ND} / \mathrm{ND}$ & $+1-$ & $+1-$ & $-1-$ & $-1-$ \\
\hline 3-Hydroxybenzoate & $+/+$ & $+/+$ & $+/+$ & $+/+$ & $+/+$ & $+/+$ & $+/+$ & $+1+$ & $\mathrm{ND} / \mathrm{ND}$ & $+/+$ & $+/+$ & $+1+$ & $+/+$ \\
\hline 4-Hydroxybenzoate & $+/+$ & $+/+$ & $+/+$ & $+/+$ & $+/+$ & $+/+$ & $+/+$ & $+/+$ & $\mathrm{ND} / \mathrm{ND}$ & $+/+$ & $+/+$ & $+/+$ & $+/+$ \\
\hline 2-Fluorobenzoate & $+/+$ & $+/+$ & $+/+$ & $+/+$ & $-1+$ & $-1+$ & $+/+$ & $+/+$ & $-/+$ & $+/+$ & $+/+$ & $-/+$ & $-/+$ \\
\hline 3-Fluorobenzoate & $+1-$ & $-1-$ & $+1-$ & $-1-$ & $+1-$ & $-1-$ & $-1-$ & $-1-$ & $-1-$ & $-1-$ & $-1-$ & $-1-$ & $-1-$ \\
\hline 4-Fluorobenzoate & $+1+$ & $-/+$ & $-1+$ & $-1+$ & $+/+$ & $+1+$ & $-1+$ & $-1+$ & $-1+$ & $-1-$ & $-1-$ & $-/+$ & $-1-$ \\
\hline 3-Chlorobenozate & $-1+$ & $-1+$ & $-1+$ & $-1+$ & $-1-$ & $-1-$ & $-1-$ & $-1+$ & $-1-$ & $-1-$ & $-1-$ & $-1-$ & $-1-$ \\
\hline 3-Bromobenzoate & $-1+$ & $-/+$ & $-1+$ & $-1+$ & $-1-$ & $-1-$ & $-1-$ & $-1+$ & $-1-$ & $-1-$ & $-1-$ & $-1-$ & $-1-$ \\
\hline 3-Methylbenzoate & $-/+$ & $-/+$ & $-1+$ & $-/+$ & $-1-$ & $-1-$ & $-/+$ & $-/+$ & $-1-$ & $-1-$ & $-1-$ & $-1-$ & $-1-$ \\
\hline
\end{tabular}


Table 6. DNA-DNA hybridization between strains of Azoarcus and Thauera

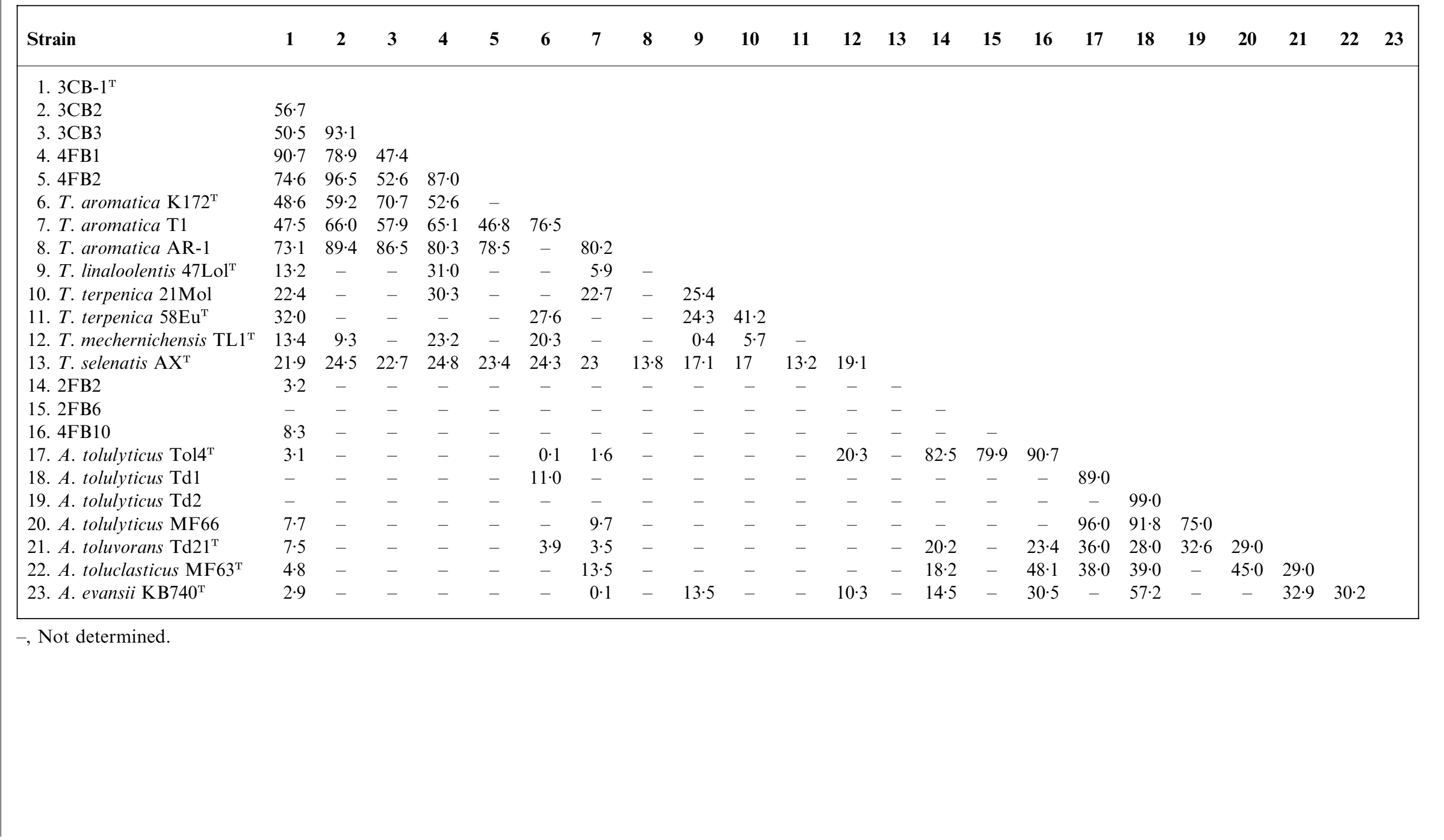



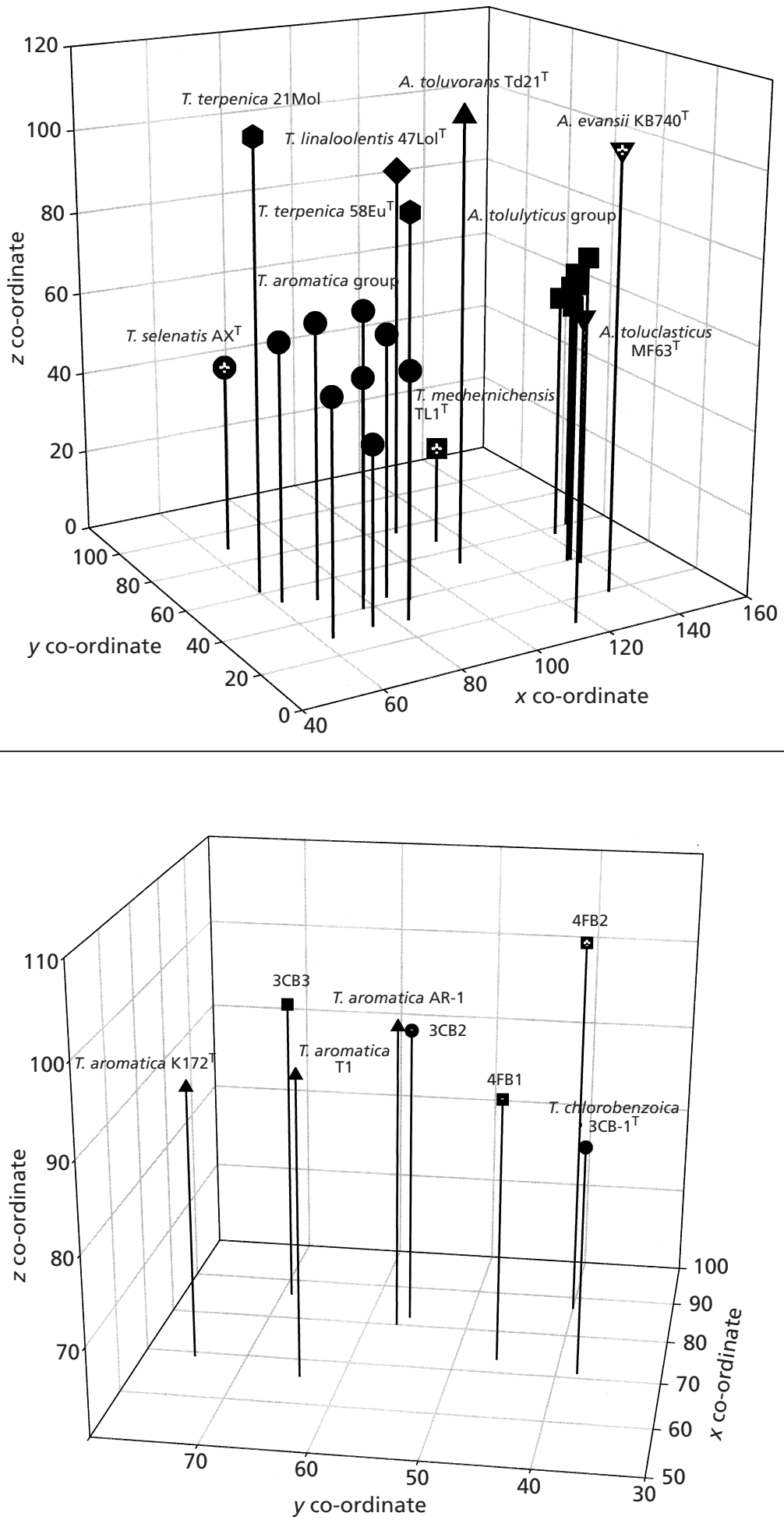

Fig. 5. Three-dimensional representation of the strains of the genera Azoarcus and Thauera. Three-dimensional co-ordinates were calculated from the data from DNA-DNA hybridization. Strains in the $T$. aromatica (O) and A. tolulyticus ( $\boldsymbol{\square})$ groups are not individually labelled.
Fig. 6. Three-dimensional representation of strains in the species Thauera aromatica and Thauera chlorobenzoica. genera Azoarcus and Thauera (Fig. 5) demonstrates that $A$. tolulyticus strains and strains $2 \mathrm{FB} 2,2 \mathrm{FB} 6$ and $4 \mathrm{FB} 10$ are tightly grouped. The strains of the species $T$. aromatica and strains 3CB2, 3CB3, 4FB1 and 4FB2 also formed a cluster. However, detailed differentiation of the $T$. aromatica strains (Fig. 6) showed the complexity of this species. Strains K172 ${ }^{\mathrm{T}}$, T1 and AR-
1 of the species $T$. aromatica and strains $3 \mathrm{CB} 2$ and $3 \mathrm{CB} 3$ grouped together and were located separately from the other strains. The fluorobenzoate-degrading strains $4 \mathrm{FB} 1$ and $4 \mathrm{FB} 2$, sharing $87 \%$ DNA similarity (Table 6), were grouped together with strain $3 \mathrm{CB}-1^{\mathrm{T}}$, which was previously proposed as $T$. aromatica genomovar chlorobenzoica (Song et al., 2000a). 

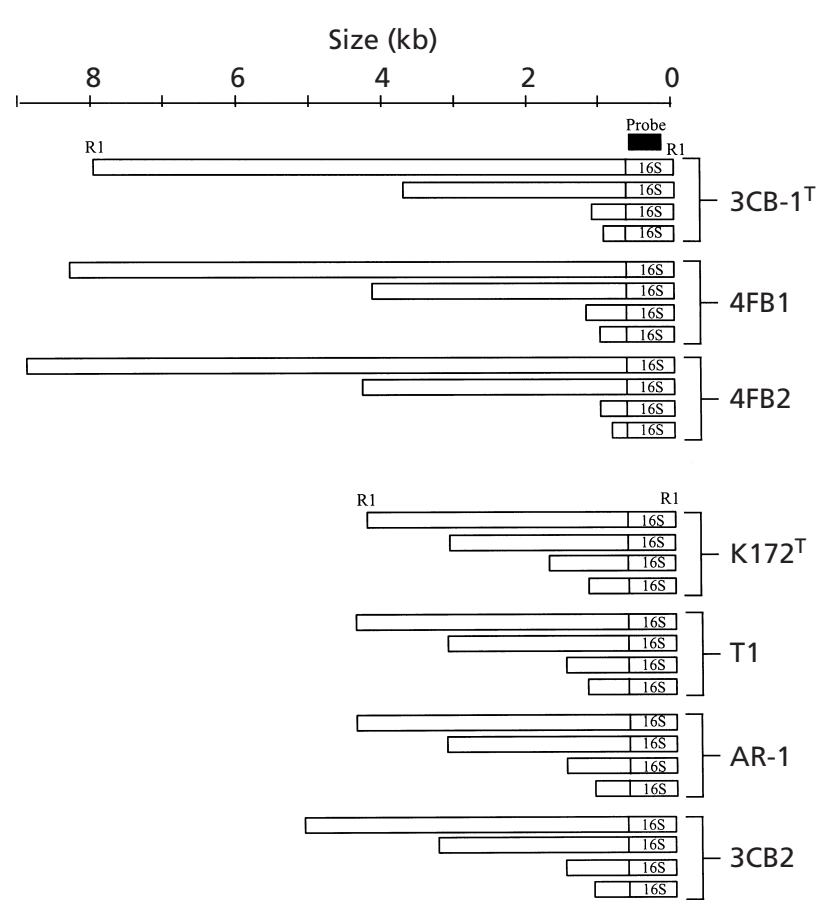

Fig. 7. Ribotype patterns of strains $3 C B 3,4 F B 1,4 F B 2$ and $3 C B-1^{\top}$ and $T$. aromatica strains $\mathrm{K} 172^{\top}{ }^{\top}, \mathrm{T} 1$ and $\mathrm{AR}-1$. DNA samples were digested with EcoRI and a 500 bp $16 \mathrm{~S}$ rRNA gene probe from $E$. coli was used for hybridization.

\section{$16 S$ rRNA gene mapping (ribotyping)}

Halobenzoate-degrading strains assigned to the genus Thauera and strains in the species T. aromatica were examined. Ribotyping of the DNA samples digested with EcoRI provided clear banding patterns and allowed the detection of four different sizes of fragments from each sample (Fig. 7), indicating that the strains had four copies of $16 \mathrm{~S}$ rRNA gene in their genomes. The copy numbers of $16 \mathrm{~S}$ rRNA genes in marine bacteria were determined in the same way (Kerkhof \& Speck, 1997). On the basis of restriction fragment polymorphism, two distinct groups are apparent. T. aromatica strains $\mathrm{K} 172^{\mathrm{T}}$, $\mathrm{T} 1$ and $\mathrm{AR}-1$ and strain $3 \mathrm{CB} 2$ formed one group, and $T$. aromatica genomovar chlorobenzoica $3 \mathrm{CB}-1^{\mathrm{T}}$ and strains $4 \mathrm{FB} 1$ and 4FB2 formed another (Fig. 7). In agreement with the analysis of DNA-DNA hybridization, strains $3 \mathrm{CB} 2$ and $3 \mathrm{CB} 3$ are assigned to the species $T$. aromatica, having the capacity to degrade halobenzoate under denitrifying conditions. However, strains $3 \mathrm{CB}-1^{\mathrm{T}}, 4 \mathrm{FB} 1$ and $4 \mathrm{FB} 2$ should be separated as a new species.

\section{Complexity of the genus Thauera}

The definition of the genus Thauera is quite complex, since it includes a variety of morphological and physiological attributes, some of which could justify subdivision into at least two genera. Thus, whilst $T$. selenatis (the type species of the genus), T. terpenica and T.mechernichensis have cells that are each motile by means of a single polar flagellum, $T$. aromatica and $T$. chlorobenzoica sp. nov. have a type of flagellation that has been designated as 'degenerately peritrichous'. The species $T$. linaloolentis cannot be included in the discussion in view of the fact that we could never detect either motility or the presence of flagella in the cells.

As a result of the discovery of the peritrichous flagellation of $T$. aromatica, and in view of the weight assigned to morphological attributes in classical bacterial taxonomy, we have already mentioned the evident heterogeneity that perhaps points to the existence of a separate phylogenetic category. In support of this opinion, the phylogenetic analysis of 16S rRNA sequences (Fig. 1) and the three-dimensional representation of DNA similarities among the strains (Fig. 5) all point to a separation of $T$. aromatica and $T$. chlorobenzoica from the remaining species of Thauera. This argument is also supported by physiological differences between the two groups. Future studies including many more strains might provide a more solid basis for a proposal of differentiation at the generic level.

\section{Description of Thauera chlorobenzoica sp. nov.}

Thauera chlorobenzoica (chlor.o.ben.zo'i.ca. M. L. adj. chloro pertaining to chlorine, from Gr. adj. chloros pale green; M.L. adj. benzoicus pertaining to benzoic acid; M.L. fem. adj. chlorobenzoica indicating the ability to utilize chlorobenzoic acid).

Cells are short, fat rods with lengths of $1 \cdot 2-2 \cdot 7 \mu \mathrm{m}$ and widths of $0.85-0.97 \mu \mathrm{m}$ and with 'degenerately peritrichous' flagellation. Fig. 4 shows the cell morphology and flagellation of strain 4FB2. All of the strains are oxidase- and catalase-positive. The predominant fatty acids are 10:0 3-OH, 12:0, 16:167c, 16:0 and $18: 1 \omega 7 c$, and a small amount of $17: 0$ cyclo fatty acid is also found. They can grow under aerobic and denitrifying conditions with acetate, adipate, butyrate, glutamate, malate, ornithine, pyruvate, succinate, benzoate, phenylacetate, vanillate, 3-hydroxybenzoate and 4-hydroxybenzoate. Under denitrifying conditions, 3-aminobenzoate, 2-fluorobenzoate and 4fluorobenzoate are used. In addition, strains $3 \mathrm{CB}-1^{\mathrm{T}}$ and 3BB1 can use 3-chlorobenzoate, 3-bromobenzoate and 3-methylbenzoate under denitrifying conditions. The analysis of the $16 \mathrm{~S}$ rRNA genes shows sequence similarity to T. aromatica $\mathrm{K} 172^{\mathrm{T}}$ of more than $98 \%$. Strains $3 \mathrm{CB}-1^{\mathrm{T}}$, $4 \mathrm{FB} 1$ and $4 \mathrm{FB} 2$ showed very similar ribotyping patterns, distinct from that of $T$. aromatica K172 ${ }^{\mathrm{T}}$. The genomic DNA similarity measured using DNA-DNA hybridization is more than $70 \%$ within the species and in the range $45-65 \%$ with respect to $T$. aromatica strains $\mathrm{K} 172^{\mathrm{T}}$ and $\mathrm{T} 1$.

Strain $3 \mathrm{CB}-1^{\mathrm{T}}$ was initially proposed as Thauera aromatica genomovar chlorobenzoica (Song et al., 2000a) because insufficient information was available 
to differentiate it as a new species. However, additional isolates capable of halobenzoate degradation under denitrifying conditions were found to belong to this genomovar group (4FB1, 4FB2 and 3BB1) and showed clear genetic differences from the type strain of $T$. aromatica, $\mathrm{K} 172^{\mathrm{T}}$, and closely grouped strains.

Strains $3 \mathrm{CB}-1^{\mathrm{T}}$, $4 \mathrm{FB} 1,4 \mathrm{FB} 2$ and $3 \mathrm{BB} 1$ are proposed as members of the new species Thauera chlorobenzoica sp. nov. The type strain is strain $3 \mathrm{CB}-1^{\mathrm{T}}(=\mathrm{ATCC}$ $\left.700723^{\mathrm{T}}\right)$.

\section{ACKNOWLEDGEMENTS}

This work was supported by grants from the United States Environmental Protection Agency (R822457) and the Office of Naval Research (N00014-94-0434 and N0014-99-10761).

\section{REFERENCES}

Anders, H.-J., Kaetzke, A., Kämpfer, P., Ludwig, W. \& Fuchs, G. (1995). Taxonomic position of aromatic-degrading denitrifying pseudomonad strains K 172 and KB 740 and their description as new members of the genera Thauera, as Thauera aromatica sp. nov., and Azoarcus, as Azoarcus evansii sp. nov., respectively, members of the beta subclass of the Proteobacteria. Int $J$ Syst Bacteriol 45, 327-333.

Braun, K. \& Gibson, D. T. (1984). Anaerobic degradation of 2aminobenzoate (anthranilic acid) by denitrifying bacteria. Appl Environ Microbiol 48, 102-107.

Devereux, J., Haeberli, P. \& Smithies, O. (1984). A comprehensive set of sequence analysis programs for the VAX. Nucleic Acids Res 12, 387-395.

Evans, P. J., Mang, D. T., Kim, K. S. \& Young, L. Y. (1991). Anaerobic degradation of toluene by a denitrifying bacterium. Appl Environ Microbiol 57, 1139-1145.

Felsenstein, J. (1985). Confidence limits on phylogenies: an approach using the bootstrap. Evolution 39, 783-791.

Foss, S. \& Harder, J. (1998). Thauera linaloolentis sp. nov. and Thauera terpenica sp. nov. isolated on oxygen-containing monoterpenes (linalool, menthol, and eucalyptol) and nitrate. Syst Appl Microbiol 21, 365-373.

Fries, M. R., Zhou, J., Chee-Sanford, J. \& Tiedje, J. M. (1994). Isolation, characterization, and distribution of denitrifying toluene degraders from a variety of habitats. Appl Environ Microbiol 60, 2802-2810.

Gallus, C., Gorny, N., Ludwig, W. \& Schink, B. (1997). Anaerobic degradation of $\alpha$-resorcylate by a nitrate-reducing bacterium, Thauera aromatica strain AR-1. Syst Appl Microbiol 20, $540-544$.

Häggblom, M. M. \& Young, L. Y. (1999). Anaerobic degradation of 3-halobenzoates by a denitrifying bacterium. Arch Microbiol 171, 230-236.

Harms, G., Rabus, R. \& Widdel, F. (1999). Anaerobic oxidation of the aromatic plant hydrocarbon $p$-cymene by newly isolated denitrifying bacteria. Arch Microbiol 172, 303-312.

Hildebrand, D. C., Schroth, M. N. \& Huisman, O. C. (1982). The DNA homology matrix and non-random variation concepts as the basis for the taxonomic treatment of plant pathogenic and other bacteria. Annu Rev Phytopathol 20, 235-256.

Hildebrand, D. C., Huisman, O. C \& Schroth, M. N. (1984). Use of DNA hybridization values to construct three-dimensional models of fluorescent pseudomonad relationships. Can $J$ Microbiol 30, 306-315.

Johnson, J. L. (1994a). Similarity analysis of rRNAs. In Methods for General and Molecular Bacteriology, pp. 683-700. Edited by P. Gerhardt, R. G. E. Murray, W. A. Wood \& N. R. Krieg. Washington, DC: American Society for Microbiology.

Johnson, J. L. (1994b). Similarity analysis of DNAs. In Methods for General and Molecular Bacteriology, pp. 655-682. Edited by P. Gerhardt, R. G. E. Murray, W. A. Wood \& N. R. Krieg. Washington, DC: American Society for Microbiology.

Kerkhof, L. J. \& Speck, M. (1997). Ribosomal RNA gene dosage in marine bacteria. Mol Mar Biol Biotechnol 6, 260-267.

Kimura, M. (1980). A simple method for estimating evolutionary rates of base substitutions through comparative studies of nucleotide sequences. J Mol Evol 16, 111-120.

Leifson, E. (1951). Staining, shape, and arrangement of bacterial flagella. J Bacteriol 62, 377-389.

Macy, J. M., Rech, S., Auling, G., Dorsch, M., Stackebrandt, E. \& Sly, L. I. (1993). Thauera selenatis gen. nov., sp. nov., a member of the beta subclass of Proteobacteria with a novel type of anaerobic respiration. Int J Syst Bacteriol 43, 135-142.

Maniatis, T., Fritsch, E. R. \& Sambrook, J. (1982). Molecular Cloning : a Laboratory Manual. Cold Spring Harbor, NY : Cold Spring Harbor Laboratory.

Mesbah, M., Premachandran, U. \& Whitman, W. B. (1989). Precise measurement of the $\mathrm{G}+\mathrm{C}$ content of deoxyribonucleic acid by high-performance liquid chromatography. Int $J$ Syst Bacteriol 39, 159-167.

Rabus, R. \& Widdel, F. (1995). Anaerobic degradation of ethylbenzene and other aromatic hydrocarbons by new denitrifying bacteria. Arch Microbiol 163, 96-103.

Reinhold-Hurek, B., Hurek, T., Gillis, M., Hoste, B., Vancanneyt, M., Kersters, K. \& De Ley, J. (1993). Azoarcus gen. nov., nitrogenfixing proteobacteria associated with roots of Kallar grass (Leptochloa fusca (L.) Kunth), and description of two species, Azoarcus indigens sp. nov. and Azoarcus communis sp. nov. Int J Syst Bacteriol 43, 574-584.

Saitou, N. \& Nei, M. (1987). The neighbor-joining method: a new method for reconstructing phylogenetic trees. Mol Biol Evol 4, 406-425.

van Schie, P. M. \& Young, L. Y. (1998). Isolation and characterization of phenol-degrading denitrifying bacteria. Appl Environ Microbiol 64, 2432-2438.

Scholten, E., Lukow, T., Auling, G., Kroppenstedt, R. M., Rainey, F. A. \& Diekmann, H. (1999). Thauera mechernichensis sp. nov., an aerobic denitrifier from a leachate treatment plant. Int $J$ Syst Bacteriol 49, 1045-1051.

Smibert, R. M. \& Krieg, N. R. (1994). Phenotypic characterization. In Methods for General and Molecular Bacteriology, pp. 607-654. Edited by P. Gerhardt, R. G. E. Murray, W. A. Wood \& N. R. Krieg. Washington, DC: American Society for Microbiology.

Song, B., Young, L. Y. \& Palleroni, N. J. (1998). Identification of denitrifier strain $\mathrm{T} 1$ as Thauera aromatica and proposal for emendation of the genus Thauera definition. Int $J$ Syst Bacteriol 48, 889-894.

Song, B., Häggblom, M. M., Zhou, J., Tiedje, J. M. \& Palleroni, N. J. (1999). Taxonomic characterization of denitrifying bacteria that degrade aromatic compounds and description of Azoarcus toluvorans sp. nov. and Azoarcus toluclasticus sp. nov. Int J Syst Bacteriol 49, 1129-1140. 
Song, B., Palleroni, N. J. \& Häggblom, M. M. (2000a). Description of strain 3CB-1, a genomovar of Thauera aromatica, capable of degrading 3-chlorobenzoate coupled to nitrate reduction. Int $J$ Syst Evol Microbiol 50, 551-558.

Song, B., Palleroni, N. J. \& Häggblom, M. M. (2000b). Isolation and characterization of diverse halobenzoate-degrading denitrifying bacteria from soils and sediments. Appl Environ Microbiol 66, 3446-3453.

Springer, N., Ludwig, W., Philipp, B. \& Schink, B. (1998). Azoarcus anaerobius sp. nov., a resorcinol-degrading, strictly anaerobic, denitrifying bacterium. Int J Syst Bacteriol 48, 953-956.
Tschech, A. \& Fuchs, G. (1987). Anaerobic degradation of phenol by pure cultures of newly isolated denitrifying pseudomonads. Arch Microbiol 148, 213-217.

Wayne, L. G., Brenner, D. J., Colwell, R. R. \& 9 other authors (1987). Report of the ad hoc committee on reconciliation of approaches to bacterial systematics. Int $J$ Syst Bacteriol 37, 463-464.

Zhou, J., Fries, M. R., Chee-Sanford, J. C. \& Tiedje, J. M. (1995). Phylogenetic analyses of a new group of denitrifiers capable of anaerobic growth on toluene and description of Azoarcus tolulyticus sp. nov. Int J Syst Bacteriol 45, 500-506. 